\title{
Identifying the signs: The Middle to Upper Palaeolithic transition in northern Iberia from the perspective of the lithic record
}

\author{
A. Arrizabalaga ${ }^{1}$, J. Ríos-Garaizar ${ }^{2}$, J.M. Maíllo-Fernández ${ }^{3}$, \\ M.J. Iriarte-Chiapusso ${ }^{4}$ \\ 1. Research Team on Prehistory (IT-622-13). Universidad del País Vasco (UPV/EHU). Facultad de Letras. \\ Tomas y Valiente s/n. 01006 Vitoria (Spain). Email: alvaro.arrizabalaga@ehu.es \\ 2. Centro Nacional para la Investigación de la Evolución Humana (CENIEH). Paseo Sierra de Atapuerca, 3. \\ 09002 Burgos (Spain). Email: joseba.rios@cenieh.es \\ 3. Universidad Nacional de Educación a Distancia (UNED). Facultad de Geografía e Historia. Paseo Senda del \\ Rey, 7. 28040 Madrid (Spain). Email: jlmaillo@geo.uned.es \\ 4. IKERBASQUE - Universidad del País Vasco (UPV/EHU). Facultad de Letras. Tomas y Valiente s/n. 01006 \\ Vitoria (Spain). Email: mariajose.iriarte@ehu.es
}

\begin{abstract}
:
The lithic record, together with archaeozoological remains, makes up the most abundant assemblages at European Palaeolithic sites. During many decades in the twentieth century, the classical typological analysis (the Bordesian paradigm) has been used to articulate the sequencing of the different cultural and chronostratigraphic units. At the same time, since the 1960s an alternative methodology known as Analytical Typology, proposed by Georges Laplace, has been available. The sophistication of the statistical procedures used by Analytical Typology is the reason given by many prehistorians for avoiding this approach, in the same way that the limitations in the quantification of the results ended up discrediting Bordes and Sonneville-Bordes' method. As a first paradox, the same reasoning (in the opposite direction) rules out both methodologies. In addition, by ignoring the typological approach, we give new life to technological analysis, where qualitative information is provisionally prioritised over quantitative data. If we aim to describe the process of transition or change, then, as we have said on various occasions, the reading of the lithic record should be holistic, and cover typometrical features, the raw materials, technology, function and certainly typological traits. The alleged difficulties about the description of the different variables, their quantification and statistical analysis have been solved for some time in Laplace's methodological proposal. Ignorance of this methodology cannot be given as an excuse, fifty years after it was first formulated.
\end{abstract}

Keywords: Palaeolithic, lithics, Typology, Technology, Raw Materials, Historiography

\section{Introduction}

By far the largest part of the objects found in the course of archaeological excavations consists of the lithic assemblage, together with faunal remains, in comparison with other

Published by the School of History, Classics and Archaeology, University of Edinburgh ISSN: 2055-0472. URL: http://journals.ed.ac.uk/lithicstudies/

This work is licensed under a Creative Commons Attribution 2.5 UK: Scotland License. 
aspects of the Palaeolithic record, such as evidence of symbolic behaviour, anthropological remains and even artefacts made from organic matter. It should be noted that the interpretative weight of each part of the record cannot be directly proportional to its physical weight. It is true that the positivist urge that gripped Palaeolithic archaeology for over a century gave a disproportionate weight to industrial assemblages and Archaeology still suffers the inertia of such excesses. However, the pendulum of Epistemology should reach a position of balance between granting disproportionate importance and ignoring data which, from a quantitative point of view, is sometimes of overwhelming value.

\section{Short historical summary of the methodology of obtaining and analyzing lithic information}

To obtain a precise view of the method used to study lithic assemblages in the MiddleUpper Palaeolithic transition, we must examine the question from a diachronic perspective. Indeed, the transposition of the concept of the fossil-guide used in Geology to particular types of lithic implements marked the first decades of the articulation of the Palaeolithic in general. Until prehistoric Archaeology underwent its first great crisis of thought, with the Processualist debate in the 1950s and 60s, the level of the reading of lithic techno-complexes was schematic and sometimes caricaturesque (Arrizabalaga, 1998). The identification of supposed fossilguides in small European regions tended to mark the start of new proposals for cultural systematizations, which spread uncontrollably across Eurasia.

After the 1960s, the science reorganised its ideas in accordance with the new parameters. There were three sides to the reawakening of lithic studies applied to this period: the quantitative aspect (which was considered essential for it to be a true Science); the holistic view (to typology that had been predominant until then were added aspects such as raw materials, typometry, technology and functionality); and a more universal ambition, which included a description of these techno-complexes outside Europe. Although it took place in a disorderly way, the progressive implantation of protocols for the study of raw materials, typometry, technology, morphotypology and use-wear analysis has enabled, above all since the 1980s, an advance in our knowledge that had previously had been unimaginable. At the present time, the lithic record possesses enormous potential to explain the circumstances of a site, its position in chronocultural coordinates, the way of life of its occupants, its functionality, adaptive strategies and the exploitation of the environment, and so on. The internal dynamics of the studies have varied in different geographical areas, although in general, typological analyses have lost part of their interpretative weight in favour of other approaches, to varying degrees. Whereas French specialists have apparently ousted Typology radically in favour of studying raw materials and technological analysis, in the Anglo-Saxon world, more attention has been paid to use-wear analysis, and Typology has not been displaced, even if this aspect never held a preferential place within the concerns of the latter School.

Therefore, in the last three decades, there has been an accumulation of alternative approaches to the classic one, playing down the importance of typological research and stressing the value of the new disciplines. In the mid-1960s, to study the lithic technocomplexes of hunter-gatherer groups, there were two main proposals, both of which originated in France. These were, on one hand the accumulative method of François Bordes and Denise de Sonneville-Bordes (Bordes 1961; Sonneville-Bordes and Perrot 1954, 1955, 1956a and 1956b; Sonneville-Bordes 1985), and, on the other hand, Georges Laplace's method (Laplace 1954, 1957, 1964 and 1966). The Bordes - Sonneville-Bordes method is very well-known in its premises. It begins with a definition of a series of lithic types, which are regarded as characteristic of different periods and which are given a number in a Type-list. 
The statistics of these types in the archaeological units being described is visualised by simple indices (of end-scrapers, burins, etc.) and an accumulative graph which shows the "typical" profile of the period represented by each level, as it adds the different tools included in the reference list to the total. Following the publication of a direct criticism to the fundaments of the method (Kerrich and Clarke 1968; Sonneville-Bordes, 1975), the validity of the criteria used to define the types, their quantitative value and the meaning of the graphs began to be questioned.

Almost at the same time, G. Laplace developed so-called Analytical Typology (Laplace, 1966). The theoretical fundaments of this approach are much more elaborate, and thus avoid the most obvious faults to the Bordes - Sonneville-Bordes method. Instead of establishing the associations of characters (types) thought to be significant a priori, the articulation of retouching on a tool is broken down into successive hierarchical levels, individually described according to the successive structures that are discriminated. The quantitative evaluation of the real meaning of all the variables described is performed with a sophisticated statistical method which filters out the noise generated by small ensembles or those exhibiting little internal contrast. In this way, it is thought that the information used to reconstruct the technocomplexes is sufficiently hierarchic, detailed and statistically significant to tackle the second part of the method, referring to its quantitative and statistical reading. Due to its characteristics, this method also allows easy comparison between the different assemblages studied with the same methodology, thus multiplying its interpretative potential.

G. Laplace's approach is much more than an alternative Typology (Laplace 1963). In the first place, in its successive stages it foresees the mechanisms to include the main variables that can be described (physical, typometric, technical, modal and morphological structure), except for functional information. Secondly, it is less pre-determined that the Bordesian method, in that it applies an identical protocol to the techno-complexes, irrespective of their initial cultural classification, which can give some surprising results (and is especially suitable for the description of transition processes). Thirdly, it involves a theoretical conception of the material reality, technology and its diachronic evolution, which enables new proposals to be made for cultural systematization and firm proposals in terms of the techno-typological development of Palaeolithic communities, in a geographical and temporal setting. We might add that the method is open to new proposals, as long as these can be systematised within a general framework with no special difficulties. Finally, it adds an elaborate statistical treatment to the analysis of the data, which places the measurement before all else, in terms of the statistical significance of the sample we are working with, in comparison with the wider context of analysis. Consequences of the application of this method to large areas of southern France and northern Spain (Arrizabalaga, 1995a) have been, among others:

- the vindication of the transitional nature of the Chatelperronian.

- the proposal of endowing special importance to the Proto-Aurignacian (in the successive French sequences, Correzian, Perigordian II, Aurignacian 0 or Archaic Aurignacian) as a techno-complex representing a sudden acceleration in the leptolithisation process. (The latter terminology has been trivialised by making the Leptolithic equivalent to the Upper Palaeolithic).

- the proposal of simplifying the EUP sequence, from the embers of the model originally proposed by D. Peyrony, reignited by D. Sonneville-Bordes. This is in terms of the Chatelperronian-Aurignacian-Gravettian succession and not of the parallel development of two Aurignacian and Perigordian phyla, as had been proposed previously (Peyrony, 1936, 1948). As Laplace foresaw, no stratifications have been documented between the Chatelperronian and the Aurignacian, as might have occurred if both phyla had developed in parallel (Zilhao et alii, 2008). 
In view of the premises noted above and the perspective several decades of work has given us since the seminal proposals of both interpretation systems, it might seem logical to think that the best of each method would have been added to the techno-typological reading of EUP lithic assemblages. However, this is not the case. The criteria of the school dominating in French Palaeolithic circles for three decades imposed the Bordesian paradigm and disregarded (or eluded, ignored and boycotted) Laplace's proposal of Analytical Typology. Analytical Typology, which was received better outside France (in northern Italy and Spain) than in France itself, would only be reappraised later (in the 1990s) when almost all French Palaeolithic scholars had forsworn typological proposals in favour of the technological approach. In this epistemological shift, which affected new generations massively, all typological systems were accused of the defects attributed by Kerrich and Clarke, among others, to the type-list criterion as originally proposed by Bordes and Sonneville-Bordes. These included deficient quantification, of which Analytical Typology cannot be accused.

From a historiographic point of view, it is much more difficult to explain why a methodology is ignored, than why an alternative is accepted. Indeed, practically all the papers on lithic assemblages at Palaeolithic sites published in France in the 1960s, 70s and 80s tacitly or explicitly adopted François Bordes' (Lower and Middle Palaeolithic) or Denise de Sonneville-Bordes' (Upper Palaeolithic) type-lists. The arguments put forward for their use include their simplicity, intuitive nature, easy visualization and even "proven value". These arguments are even used after the construction of units of formal value on the basis of an accumulative type-list had been shown to be wrong. In contrast, we know of no detailed account explaining why the approach proposed by Laplace was not taken up. We have to resort to unwritten reasons: that it was a "complicated" approach, that it treated lithic technocomplexes as if they were a living creature (undervaluing the human factor and creativity) or that it used excessively sophisticated statistic calculations that make one forget, once again, that we are dealing with human production. Obviously, the weight wielded in this decision by the criterion of school is never expressed frankly.

Thus, the first striking paradox in this explanation is consummated. The dominant criterion used to abandon the Bordesian method (the deficient quantification of its interpretations) is the same one used, in the opposite sense, to elude the alternative proposal, which solved that aspect satisfactorily ("it includes excessively sophisticated statistics", they say). If, with the perspective given by time, we are unable to evaluate the essential role of statistics in the articulation of Human and Social Sciences, there is no point in making evenemential historiography. However, in addition, the massive shift of new generations of French Palaeolithic scholars towards technology has not led to the adoption of more sophisticated quantitative protocols, and this is one of the problems most often regarded as unsolved within that approach.

Unfortunately, the main actors in this personal and methodological lack of understanding disappeared a long time ago. Perhaps it is now time to make a methodological and historiographic assessment of what one or other school has contributed towards an understanding of EUP societies and the transition process from the Middle Palaeolithic. While this transition is acknowledged, since the Bordesian paradigm uses different type-lists (between which there are no connections) to study Middle Palaeolithic and Upper Palaeolithic techno-complexes, it will be very difficult to observe common traits denoting an industrial transition between both traditions. 


\section{Major developments and main contributors to research about the transition to the Upper Palaeolithic in Cantabrian Spain (north-west Iberia)}

As in the whole of Western Europe, the study of the EUP or the transition between the Middle and Upper Palaeolithic has made unprecedented progress since the early 1980s. Few significant sites with levels attributed to the late Mousterian, Chatelperronian, ProtoAurignacian or ancient Aurignacian have not been excavated or re-excavated. This is the case of key sequences in the regions of Asturias (El Conde, La Viña, Sopeña, La Güelga), Cantabria (Cueva Morín, Covalejos, El Pendo, El Castillo, Cobrante, Esquilleu) and the Basque Country (Axlor and Antoliñako Koba, in Bizkaia; Lezetxiki, Amalda, Zerratu, Labeko Koba and Aitzbitarte III, in Gipuzkoa). To these sixteen main excavations, we can add a similar number of smaller-scale actions at open-air sites (with much simpler stratigraphy) or in caves (isolated levels, such as at Balzola in Bizkaia, or containing very few remains, such as at Ekain, in Gipuzkoa). The publications with the proceedings of two conferences (Montes and Lasheras, eds., 2005; Cabrera, Bernaldo de Quirós and Maíllo 2006) reflect the recent state of the art in this part of Spain. In our opinion, this proliferation of work has not led to an equal multiplication in the information, partly because of the lack of a common methodology and an epistemological reflection on the characterisation of the periods in the transition.

Just as at other sites of a similar chronology, the imbalances in the record we noted in the first part of this paper can also be seen in Cantabrian Spain. Owing to the low number of artefacts made from organic materials that have been conserved in these levels, by far the largest part of the remains found at the main sites consists of faunal remains (accumulated either by humans or carnivores) and lithic industry. The improvements in excavation methodology, with the generalized wet or dry fine screening of the sediment, have favoured the exhaustive recovery of the lithic assemblage, unlike in old excavations, which has enabled an integral view of the chaîne opératoire.

Empirical Typology (Sonneville-Bordes and Bordes' type-lists) has been applied to nearly all the ensembles that have been cited, although it has only been used descriptively for the retouched portion ("tools") of the chaine opératoire. Some considerations have occasionally been added related to the primary level of the raw materials used (flint, quartzite, limestone, ophite, etc.) and a typometric graph of the kind proposed by Bagolini. Similarly, as an alternative to the "classic" typological analysis, the protocol of technological analysis has been applied exhaustively to certain lithic assemblages. Among the various collections to which this kind of analysis has been applied, we can highlight the studies published of Amalda (Baldeón 1990) and Esquilleu (Baena et alii.2002, 2005 and 2006), with a marked technological character.

For the reasons given above, spreading from a Basque and Catalan nucleus, Analytical Typology has been used above all at sites in the eastern sector of northern Spain, with a different view. The research associate variables related to the five structures recognised by Laplace in his works, and listed above (physical, typometric, technical, modal and morphological). Technological study, as it was understood from the empirical viewpoint, represents a fundamental complement when describing the dynamics of the assemblages, but these variables are difficult to codify and, even worse, to treat quantitatively in a way that has any meaning. To give a rather schematic example: a refitted Levallois core, in a collection with another 100 insignificant cores, does not meet the requirement of minimum numerical pertinence to be treated quantitatively, but it does require a singular qualitative assessment when the collection is being described, above all if it is supported by the presence of other remains in the same series, such as Levallois flakes supposedly made from another core. The significance held by singular elements in the description of an assemblage is corrected drastically, in this method, in accordance with their numerical weight. Among the authors 
who have contributed especially to this approach, we can cite Sáenz de Buruaga, Aguirre and Arrizabalaga, with monographs on lithic techno-complexes at sites such as Gatzarria (Sáenz de Buruaga 1991), Antoliñako koba (Aguirre 2000), Cueva Morín (Arrizabalaga 1995b, 1999d) and Labeko Koba (Arrizabalaga 2000), as well as synthesis for the eastern part of northern Spain (Arrizabalaga 1995b and 1999c).

All these contributions, together with the studies referring to particular levels or the technological dynamics of particular stratigraphic series at La Güelga (Menendez et al. 2009), Sopeña (Pinto-Llona et al 2012), El Castillo, Covalejos, Amalda, Axlor, Lezetxiki and Aitzbitarte III (Ríos-Garaizar et al. 2011) have laid on the table an open and varied range of methodological proposals, to be discussed below.

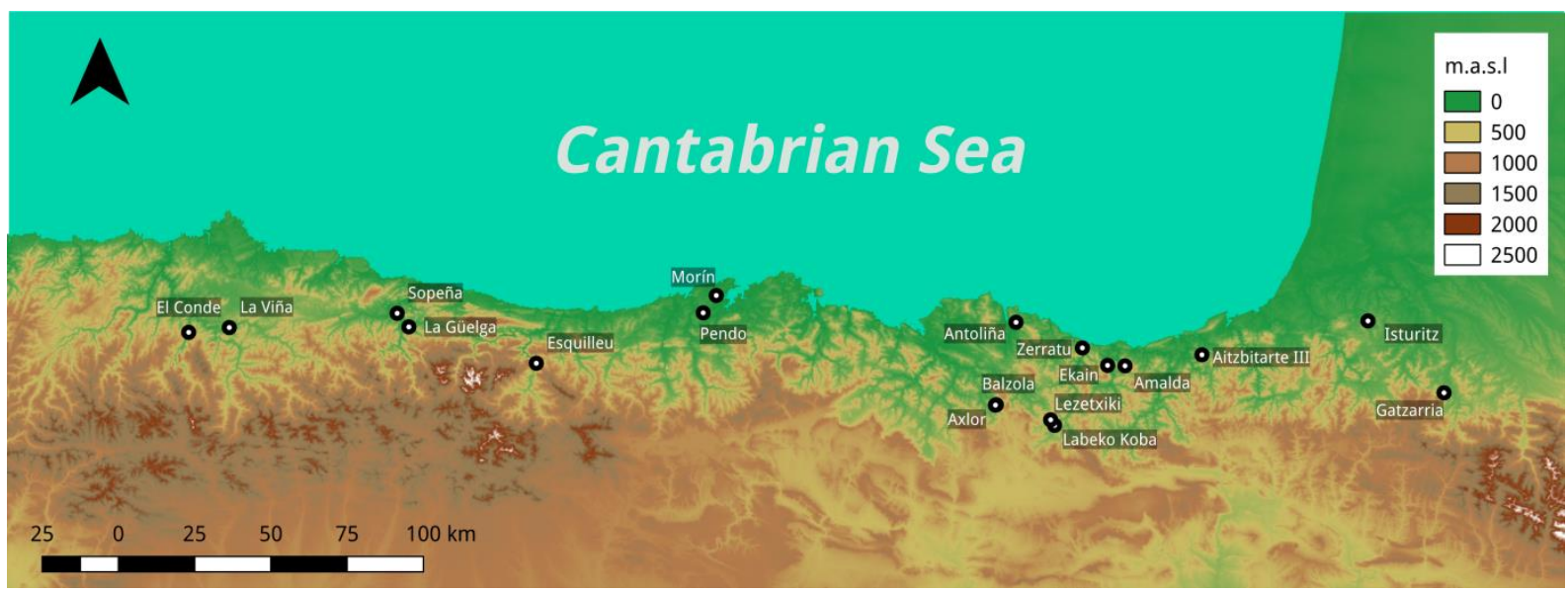

Figure 1. Map of the Cantabrian Iberian, with the cited sites.

\section{Discussion}

In the first place, we must state that this presentation aims to discuss and propose a methodology, and not to review the historiography and seek responsibilities for how we have reached the present situation. From this viewpoint, taking into account the trends that have consolidated in modern research on the transition from the Middle to Upper Palaeolithic, we would like to make a constructive proposal of a protocol for studying lithic assemblages, which will have to be adapted to the circumstances of each site. Not only the unique conservation conditions at each site, but also the methods of excavation, screening and recording, influence greatly in the last state of the assemblage.

We propose that we should lead the study of lithic evidences towards a holistic approach where all the evidences of lithic record will be analyzed in an integrated perspective to get a full view of a complex manifestation of prehistoric human behaviour.

From this reason, the protocol used for lithic assemblages should consider, as far as possible, many significant features connected with the distribution, including raw materials, the typometric characterisation of the assemblage, several technological aspects, a morphotypological description, functional assessment and as much topographical metainformation as it is possible to add. The information should be ranked and codified in such a way that it can be compared both with other sites and other stratigraphic units in the same deposit. Finally, there must be a statistical treatment of sufficient detail to be able to filter out those ensembles that are irrelevant because of their numbers, accumulation of elements on a category or excessive fragmentation of the sample.

A first approximation in this line suggests an adaptation of the general framework proposed by Laplace (which includes the systematization and ranked arrangement of characters, and advanced statistical treatment). It should be enlarged to include information 
about the raw materials and the technological description, implementing sampling of use-wear marks, with a systematic comparison of the spatial distribution of the different variables used. Within a generic framework of the neutral description of the series and primary types, it is reasonable that, for empirical study, some types formed by repeated associations of proven chronocultural value (for example, Mousterian and Chatelperronian points, Noailles burins and Dufour bladelets) should be assessed in an individualised way. This in no way stops these primary types from being included in the overall statistical calculations in identical conditions.

If the objective for each assemblage of objects is to accumulate a sufficiently large sample to be able to obtain significant conclusions, before all else we should take care in not losing sight of what we are studying and why. The universe we are characterising will give rise to different samples depending on the variables we are analysing. If, for example, we only describe the typometry of whole artefacts when they conserve the platform, by adding all the proximal fragments, the previous sample will be increased considerably. According to this principle, the primary division of the whole assemblage will be based on whether the pieces are retouched or not. Much of the fair criticism made of Typology and Technology comes precisely from the respective lack of interest in one of those two parts of the assemblage (Arrizabalaga \& Maíllo-Fernández, 2008). It is essential to study both of them at the same time with a rigorously equal protocol, enabling the reading of the entire assemblage and of its parts, when this might be significant. This will be the case, not only of morpho-technical or "typological" analysis (a form of retouch can only be described for retouched artefacts) but also of other, less obvious kinds of analysis, such as functional features. A final general consideration refers to the use of Statistics to characterise lithic ensembles. Before applying techniques specifically designed to be used with lithic assemblages, a $\chi 2$ test should be carried out to evaluate the pertinence of later tests based on the proven significance of the sample.

Lithic raw material can be described universally, in the whole assemblage being studied, though in greater detail in the dominant part of the sample. For statistical purposes, one difficulty is often the regional attribution of a reference raw material (flint or quartzite in Cantabrian Spain) which makes up over $90 \%$ of the assemblage and unbalances the statistical perception of the whole noticeably, hindering a reading of its dynamics. The inclusion of subtypes (based on the provenance if it can be determined) in the dominant raw material may help to correct this perverse effect of statistics (Tarriño, 2006).

The typometric characterisation of lithic industry has traditionally been performed in two different ways. The most common one, as proposed by Bagolini (1968), discriminates a set of modules of length and elongation (bidimensionality) obtained by a division of the linear base of the dispersion plane of the dimensions of each unfragmented object. Laplace's proposal is slightly different (Laplace 1974a and 1977), as it refers to the three dimensions of each object (tridimensionality), provides a measurement criterion (insertion in the smallest rectangle or cube) and various synthetic indices, and divides the space with logarithmic curves (based on Fibonacci's series). Laplace's proposal is more complete but more complicated to carry out and monitor. If we had to adapt a single proposal, we would propose to systematise the measurement criterion (Laplace's method or any other is acceptable, as long as it is explicit and consistent, and affects the three main dimensions). We would maintain the indices proposed by Laplace, even if they cannot be treated statistically, as they are not a continuous variable, unlike direct measurements. As regards the position on the length/breadth dispersion plane, both Laplace's and Bagolini's methods finally require a graphic representation, as modules cannot be assigned easily based on the measurements themselves. We could accept either of the methods or develop a third with modules assigned directly based on the objects and their indices, with numerical thresholds that are indicated explicitly. 
Other perspective can be proposed for typometrical analysis based on non aprioristic classifications or indices, even if used for archaeological purposes not directly related to lithic analysis. Many statistical methods as K-means (Kintigh 1990) or Mixture analysis (Monchot et al. 2005) serve to distinguish size groups within a continuous distribution. This has been successfully used to identify size-related specific productions in Middle and Upper Palaeolithic (González-Urquijo et al. 2006; Rios-Garaizar 2010).

We believe this last aspect to be of high value, because the characterisations of the assemblages corresponding to the transition in Europe are full of imprecise descriptions that avoid the quantification: "assemblage with many blades", "series still with debitage on flakes", "tendency towards microlithics", etc. Whatever criteria are adopted to measure the objects, represent and interpret their distribution and assign them to modules that are later studied statistically, these should be made clear and explicit in the publication of the results. As has already been stated, the basis of the statistical treatment of Typometry could be the distribution of ranked modules that combine various intervals of different of the dimensions taken. However, other alternatives have also been considered (Arrizabalaga 1997, 1999a and 1999b).

In the last decades, lithic technology has substituted somehow the bordesian typological classifications as the method to describe and name a given lithic assemblage in Western Europe. Born with a different purpose, technological approaches have slid from the analysis and description of technical processes to the recognition of particular features or technical systems, that can be linked with determinate cultures or periods, becoming so the new taxonomy of lithic industry. Improved with Experimental Archaeology, the refitting of punctual lithic sequences and the reading of diacritics, this updated technological approach has been able to define real techno-types and to give us an accurate tool for a better understanding of the lithic production mechanisms. That can be exemplified in the works of Pellegrin about Chatelperronian, or the current structuration of Aurignacian based on the features of the bladelet production. The main potential problem of this view is that they could fail in the same errors as typology, trying to fit discrete and contextual behaviours into cultural classifications. Nevertheless the precise definition of different technical procedures has been crucial for the use of technological approaches as a way to understand technological organization. This economic focus is more present in the US technological approaches (Kuhn 1995, Tostevin 2000) and has been used also by some French and Spanish scholars (Moncel et al. 2011).

Use wear analysis had played a less relevant role in these studies. There are different problems with this method derived from the expertise based, non-quantitative, recognition of wear traces; the problems of conservation that bias the possibilities of use interpretation; the dependence on true experimentation and the impossibility to produce direct cultural interpretations as was intended in the Binford-Bordes discussion. This tendency has been turned in the last decades and use wear has been applied to recognize concrete and highly significant types of tools as points or armatures (Galván Santos et al. 2007-2008; Normand et al. 2008; Plisson and Schmider 1990; Porraz et al. 2010; Rios-Garaizar 2008; Villa et al. 2009 ) and to assess questions about technological organization or space use (Bourguignon et al. 2008; Grigoletto et al. 2008; Ortega et al. 2006; Ríos-Garaizar 2010; Texier et al. 1998).

The technological variable is probably the most difficult to rank and quantify in a systematic study. There is clearly the possibility of classifying the whole assemblages according to concepts that will give information about its integrity (fragmented pieces compared with whole pieces), or the Chaîne Opératoire (balance between the different parts of it) or the functional characterisation of the site (workshop, hunting post, settlement, etc.). Equally, there is evidence that can help us to situate the assemblage chronoculturally (such as the classification according to the platforms that have been preserved). Certain portions of the 
Chaîne Opératoire which are usually abundant and may have interesting technological readings (cores, refreshing flakes, burin spalls, etc.) may be classified and analysed individually. However, most of the variables with technological importance tend to be underrepresented and should be analysed specifically, from a qualitative viewpoint. Thus, if a re-fit can be completed, if the presence of knapping techniques such as Levallois, Kombewa and centripetal, is observed, the assessment of this data will be qualitative rather than quantitative. The same can be said about the main analytical tools of the French Technological School for the study of Palaeolithic assemblages: refitting, "mental refitting", a diacritical reading and the articulation of the functional study with the most technological part of the reconstruction (Inizan et al. 1995; Karlin 1992; Pelegrin et al. 1988). All these, although they provide very relevant information for an understanding of the series, hardly meet the conditions laid down for strict quantitative analysis: ranking of characters, codification of the variables and crossing a statistically provable threshold of significance. This does not reduce the analysis to irrelevance, from a quantitative point a view, but it does force us to think of this information on a different level until the difficulties can be overcome at least partially.

Nevertheless the identification, classification and measurement of certain technological traits (as typometry, section morphology, platform morphology and dimension, knapping angles, number and orientation of previous scar removals, section curvature, presence of cortex, etc.) can be produced to obtain sufficient base to characterize statistically different productions and the degree of reduction sequence fragmentation. Controlled knapping experimentations offer also a quantitative base to compare the expected panoply of lithic remains derived from each production with the real lithic assemblage.

The last level to be studied is the modal-morphotechnical one, which mainly affects retouched ensembles, "tools" and "implements". In general, the classification and description of forms of retouch, typological groups and primary types proposed by Laplace (Laplace $1974 \mathrm{~b}$ and 1987) was formulated bearing in mind the described protocol of quantification, which does not imply that it cannot be improved, particularly for some typological groups, such as the Bc (becs) for example. Recently, from the viewpoint of technology, complementary, and not alternative, analytical mechanisms have been proposed for primary groups, such as burins, end-scrapers and backed artefacts. In our opinion, the association of characters recognised as significant and specific (not attributable to chance or convergence) may equally be taken into account, to enrich the descriptive discourse of the assemblages. However, in our own experience, these are somewhat intangible in more detailed research, because of their very nature: the association of characters that are related to a particular type is usually so intuitive and intricate that no variable is exclusive to the type or exclusive for its classification. In short, they are typological paradoxes, unusual but recognisable.

At this modal-morphotechnical level, Analytical Typology reaches the status of metamethodology. As well as the classification, description, breaking-down into characters and systematization of the lithic material record of Palaeolithic groups, it then proposes its use according to the elementary rules of Statistics to reach conclusions about the diachronic evolution of the material culture. Leaving other considerations on one side, the level of descriptive standardisation enabled by Analytical Typology favours a rapid comparison between the results of assemblages from a diachronic sequence, between deposits believed to be coetaneous, and across wide regional contexts, using both viewpoints. This gives Analytical Typology high potential for wider use, unfortunately underemployed.

Finally, outside the range of the direct application of this discipline lies the exploitation of the topographic meta-information about the lithic record. If we include the position of each object in the deposit together with the rest of the information, we will obtain an extremely powerful tool to explain the functionality of the site and its possible differentiated activity areas, the integrity of the stratigraphic record, the character of simple occupation or 
"palimpsest" of the unit being studied, and so on. However, this level of the analysis should be the topic of a different study, owing to the quality of the information it provides. To say the truth, this approach should be placed among the great contributions to technological studies made by French Palaeolithic scholars in recent decades.

\section{Conclusions}

The reconstruction of the evolutionary processes in lithic techno-complexes during the Palaeolithic in general and the Middle-Upper Palaeolithic transition in particular has been hindered by the diversity in the methodologies used to approach it (Clark, 2009). Some proposals are even teleologically hostile to the description of transition processes as they use different premises according to whether the ensemble is thought to belong to the Middle Palaeolithic or the Upper Palaeolithic. Underlying this first choice between Bordes' or Sonneville-Bordes' type-lists is certain biological prejudice about which human species was responsible for the respective material cultures and the impossibility of any information being transmitted between each species. As can be argued from a superficial reading of the Middle Stone Age in Africa, attributed to modern humans, it is not even necessary to foresee any transfer of technological information between the species, though this is not the discussion that interests us here. In our opinion, if we aim to advance in the right direction, in the first place we should adopt methodological conventions that allow us to compare the results obtained for different chronologies (particularly from both sides of the transition process), stratigraphic series and regions, confident that the similarities and differences are not related to the different approaches used. We are proposing some general lines for this reshaped analytical methodology for the lithic record, after explaining the reasons that have guided us in the adoption of different alternatives. As a final goal, we always pursue the verification of our impressions through statistical tests that enable us to filter out background noise.

\section{References}

Aguirre, M. 2000, El paleolítico de Antoliñako Koba (Gautegiz-Arteaga, Bizkaia): secuencia estratigráfica y dinámica industrial. Avance de las campañas de excavación 1995-2000, Illunzar, 4: 39-81. (in Spanish) ("The Palaeolithic of Antoliñako koba (GautegizArteaga, Bizkaia): stratigraphic sequence and industrial dynamics. An advance to 19952000 excavation seasons")

Arrizabalaga, A. 1995a, La industria lítica del Paleolítico superior inicial en el oriente cantábrico, Unpublished Doctoral Thesis, Department of Geography, Prehistory and Archaeology, Universidad del País Vasco, Vitoria, 1000 p. (in Spanish) ("The Early Upper Palaeolithic lithic industry in the eastern Cantabrian region")

Arrizabalaga, A. 1995b, Grotta Morín (Cantabria, Spagna). Livelli del Paleolitico superiore iniziale, Archivio de Tipologia Analitica 1993, Universitá di Siena, Siena, 135 p. (in Italian) ("Morin Cave (Cantabria, Spain). Early Upper Paleolithic levels")

Arrizabalaga, A. 1997, Técnicas de modelización tipométrica en series líticas. Nubes de puntos, análisis de superficie de tendencia y de agrupamiento, Isturitz. Cuadernos de Sección de Prehistoria y Arqueología, 7: 165-192. (in Spanish) ("Typometrical modelization techniques for lithic assemblages. Point clouds, trend surface and cluster analysis")

Arrizabalaga, A. 1998, La gestación de la Prehistoria europea: el ejemplo del Paleolítico superior inicial en el sudoeste francés, In: Antoine d'Abbadie y su época, Congreso 
Internacional, Eusko Ikaskuntza-Euskaltzaindia, Donostia: p. 95-116. (in Spanish) ("The dawn of European Prehistory: Early Upper Palaeolithic example in southwestern France")

Arrizabalaga, A. 1999a, Metrical characterization of the lithic industries, In: New Techniques for Old Times. Computer Aplications in Archaeology 1998, (Barceló, J.A., Briz, I., Vila, A., Eds.), B.A.R. International Series Vol. 757, Archaeopress, Oxford: p. 209-212.

Arrizabalaga, A. 1999b, Técnicas de modelización tipométrica en series líticas. Análisis por módulos y tratamiento estadístico, Isturitz. Cuadernos de Sección de Prehistoria y Arqueología, 10: 287-304. (in Spanish) ("Typometrical modelization techniques for lithic assemblages. Module analysis and statistical treatment")

Arrizabalaga, A. 1999c, El Paleolítico superior inicial en el Pirineo Occidental y Montes Vascos, In: XXIV ${ }^{o}$ Congreso Nacional de Arqueología, Tomo 1, Cartagena, Instituto de Patrimonio Histórico, Murcia: p. 43-52. (in Spanish) ("The Early Upper Palaeolithic in the western Pyrenees and Basque mountains")

Arrizabalaga, A. 1999d, La génesis del Leptolítico en el yacimiento de Cueva Morín (Cantabria), In: XXIV Congreso Nacional de Arqueología, Tomo 1, Cartagena, Instituto de Patrimonio Histórico, Murcia: p. 71-80. (in Spanish) ("The genesis of Leptolithic in the site of Cueva Morín (Cantabria)")

Arrizabalaga, A. 2000, Los tecnocomplejos líticos del yacimiento arqueológico de Labeko Koba (Arrasate, País Vasco), In: Labeko Koba (País Vasco). Hienas y Humanos en los albores del Paleolítico superior, (Arrizabalaga, A. \& Altuna J., Eds.), Munibe (Antropologia-Arkeologia) 52: 193-343. (in Spanish) ("Lithic technocomplexes in the archaeological site of Labeko Koba (Arrasate, Basque Country)")

Arrizabalaga, A., Maíllo-Fernández, J. M. 2008, Technology vs. Typology? The Cantabrian Archaic Aurignacian/Protoaurignacian example. In: Typology vs Technology, (Aubry, Th., Almeida, F., Araujo, A. C., Tiffagom, M., Eds.), BAR International Series, Vol. 1831, Oxbow, Oxford: p. 133-139.

Baena, J., Carrión, E. 2002, El nivel III de la cueva del Esquilleu (Castro-Cillórigo, Cantabria), Zephyrus 55: 61-76. (in Spanish) ("Level III at the cave of Esquilleu (Castro-Cillórigo, Cantabria)")

Baena, J., Carrión, E. \& Velázquez, R. 2006, Tradición y coyuntura: claves sobre la variabilidad del Musteriense occidental a partir de la cueva del Esquilleu. In: En el centenario de la cueva de El Castillo: el ocaso de los Neandertales, (Cabrera-Valdés, V., Bernaldo de Quirós, F. \& Maíllo-Fernández, J. M., Eds.), UNED-Caja Cantabria, Santander: p. 249-267. (in Spanish) ("Tradition and circumstances: clues on western Mousterian variability in the cave of Esquilleu")

Baena, J., Carrión, E., Velázquez, R. \& Manzano, I. 2005, Ocupaciones musterienses en la comarca de Liébana (Occidente de Cantabria, España). In: Geoarqueología y

Patrimonio en la Península Ibérica y el entorno mediterráneo, (Santonja, M., PérezGonzález, A., \& Machado, M.J., Eds.), Soria: p. 113-125. (in Spanish) ("Mousterian occupations in the Liebana district (West Cantabria, Spain)")

Baldeón, A. 1990, Las industrias de los niveles paleolíticos, In: La Cueva de Amalda (Zestoa, País Vasco). Ocupaciones paleolíticas y postpaleolíticas, (Altuna, J., Baldeón, A., Mariezkurrena, K., Eds.), Eusko Ikaskuntza, San Sebastián: p. 63-115. (in Spanish) ("The industries of the Palaeolithic levels") 
Bagolini, B. 1968, Ricerche sulle dimensioni dei manufatti litici preistorici non ritocatti, Annali dell'Universita di Ferrara, 10: 195-219. (in Italian) ("Research on dimensions of non-retouched prehistoric lithics")

Bordes, F. 1961, Typologie du Paléolithique Ancien et Moyen. CNRS, Institut de préhistoire de l'Université de Bordeaux, Bordeaux, 85 p. (in French) ("Typology of Lower and Middle Palaeolithic")

Bourguignon, L., Blaser, F., Ríos-Garaizar, J. \& Pradet, L. 2008, L'occupation moustérienne de la doline de Cantalouette II (Creysse, Dordogne): spécificités technologiques et économiques, premiers résultats d'une analyse intégrée. In: Les sociétés $d u$ Paléolithique dans un Grand Sud-Ouest de la France: nouveaux gisements, nouveaux résultats, nouvelles méthodes, (Jaubert, J., Bordes, J.-G. \& Ortega, I., Eds.), Journées SPF, Université Bordeaux 1, Talence, 24-25 Novembre 2006. Société Préhistorique Française, 2008, Paris: p. 133-150. (in French) ("The Mousterian occupation of the sinkhole of Cantalouette II (Creysse, Dordogne): technological and economical specificities and first results of an integrated analysis")

Cabrera, V., Bernaldo de Quirós, F., Maíllo, J.M., (Eds.) 2006, En el centenario de la cueva de El Castillo: el ocaso de los Neandertales. UNED, Centro Asociado a la Universidad Nacional de Educación a Distancia en Cantabria, Santander, 537 p. (in Spanish) ("In the centenary of the cave of El Castillo: The Twilight of the Neanderthals")

Clark, G. A. 2009, Accidents of History: conceptual frameworks in Paleoarchaeology. In: Sourcebook of Palaeolithic Transitions, (Camps, M., \& Chauhan, P., Eds.), New York. Springer: p. 19-41.

Galván, B., C. M. Hernández-Gómez \& I. F. Ortega 2007-2008, Elementos líticos apuntados en el Musteriense Alcoyano: el Abric del Pastor (Alicante). Veleia, 24-25: 367-383. (in Spanish) ("Lithic pointed elements in the Mousterian from Alcoy: Abric del Pastor (Alicante)")

González-Urquijo, J. E., Ibáñez-Estévez, J.J., Ríos-Garaizar, J. \& Bourguignon, L. 2006, Aportes de las nuevas excavaciones en Axlor sobre el final del Paleolítico Medio. In En el centenario de la cueva de El Castillo: el ocaso de los Neandertales, (Cabrera, V., Bernaldo de Quirós, F. \& Maíllo, J.M., Eds.), UNED, Centro Asociado a la Universidad Nacional de Educación a Distancia en Cantabria, Santander: p. 269-291. (in Spanish) (“Contributions of new dig seasons at Axlor about the end of Middle Palaeolithic")

Grigoletto, F., Ortega, I., Rios-Garaizar, J. \& Bourguignon, L. 2008, Le Châtelperronien des Vieux Coutets (Creysse, Dordogne). Premiers éléments de réflexion. In: Les sociétés $d u$ Paléolithique dans le Grand Sud-Ouest de la France: nouveaux gisements, nouveaux résultats, nouvelles méthodes. Journées SPF, Université Bordeaux 1, Talence, 24-25 Novembre 2006, (Jaubert, J., Bordes, J.-G. \& Ortega, I., Eds.), Société Préhistorique Française, Paris: p. 245-259. (in French) ("The Chatelperronian at Vieux Coutets (Creysse, Dordogne). First elements of reflection")

Inizan, M. L., Reduron, M., Roche, H. \& Tixier, J. 1995, Technologie de la pierre taillée, C.R.E.P., Valbonne, p. 199. (in French) (“Technology of the knapped stone")

Karlin, C. 1992, Connaissances et savoir-faire: comment analyser un Processus Technique en Préhistoire. Introduction, In: Tecnología y Cadenas Operativas líticas, Mora, R., Terradas, X., \& Parpal, A., Eds.), Treballs d'Arqueologia Vol. 1, Universitat Autonoma Barcelona, Bellatera: p. 99-124. (in French) ("Knowledge and know-how: How to analyze a Technical Process in Prehistory. An introduction”) 
Kerrich, J.C., Clarke, D. L. 1968, Notes on the Possible Misuse and Errors of Cumulative Percentage Frequency Graphs for the Comparison of Prehistoric Artefact Assemblages, Proceedings of the Prehistoric Society 33: 57-69. doi:10.1017/S0079497X00014043

Kintigh, K. 1990, Intrasite Spatial Analysis: A Commentary on Major Methods. In: Mathematics and Information Science in Archaeology: A Flexible Framework, (Voorrips, A., Ed.), Studies in Modern Archaeology vol. 3, HOLOS-Verlag, Bonn: p. 165-200.

Kuhn, S. L. 1995, Mousterian lithic technology: an ecological perspective. Princeton University Press, Princeton, 209 p.

Laplace, G. 1954, Application des méthodes statistiques à l'étude du Mésolithique, Bulletin de la Société Préhistorique Française 51(3-4): 127-139. (in French) (“Application of Statistical methods to the study of Mesolithic") doi:10.3406/bspf.1954.3074

Laplace, G. 1956, Typologie statistique et évolution des complexes à lames et lamelles, Bulletin de la Société Préhistorique Française 53(5-6): 271-290. (in French) ("Statistical Typology and evolution of blade and bladelets complexes") doi:10.3406/bspf.1956.3334

Laplace, G. 1957, Typologie Analytique. Application d'une nouvelle méthode d'étude des formes et des structures aux industries à lames et lamelles, Quaternaria 4: 133-164. (in French) ("Analytical Typology. Application of a new research method of morphologies and structures to the blade and bladelets lithic industries")

Laplace, G. 1963, Réponse à François Bordes, L'Anthropologie, 67: 614-637. (in French) ("Response to François Bordes")

Laplace, G. 1964, Essai de Typologie systèmatique, Annali dell'Università di Ferrara, NS, 15(Supplement II): 1-85. (in French) (“Systematical Typology Essay”)

Laplace, G. 1966, Recherches sur l'origine et l'évolution des complexes leptolithiques, Mélanges d'Archéologie et d'Histoire de l'École Française de Rome, Suppléments Vol. 4, E. de Boccard, Paris, 586 p. (in French) ("Researches on origin and evolution of Leptolithic complexes")

Laplace, G. 1974a, Diagramme des aires et allongements: indices de grandeur absolue et quadratique de carénage, Dialektikê. Cahiers de Typologie Analytique Coarraze, 1974: 5-6. (in French) ("Diagram of areas and lengthening: absolute magnitude and squared carenity indices")

Laplace, G. 1974b, La Typologie Analytique et Structurale: Base rationnelle d'étude des industries lithiques et osseuses, In: Colloques Nationaux du C.N.R.S.: Banques des données archéologiques, 932, C.N.R.S., Paris: p. 91-143. (in French) ("Diagram of areas and lengthening: absolute magnitude and squared carenity indices")

Laplace, G. 1977, Notes de Typologie Analytique. Orientation de l'objet et rectangle minimal, Dialektikê. Cahiers de Typologie Analytique Coarraze, 1977: 32-53. (in French) ("Notes of Analytical Typology. Minimal obect and rectangle orientation")

Laplace, G. 1987, Recherches de Typologie Analytique: la grille 1986, Dialektikê. Cahiers de Typologie Analytique Coarraze, 1985-1987: 16-21. (in French) ("Researches on Analytical Typology: the 1986 grille")

Menéndez, M., Quesada, J.M., Jordá, J.F., Carral, P., Trancho, G., García, E., ÁlvarezAlonso, D., Rojo, J. \& Wood, R. 2009, Excavaciones en la cueva de La Güelga (Cangas 
de Onís), In: Excavaciones arqueológicas en Asturias (2003-2006), (Reyero, J.F., de Castro Valdés, C.G., Eds.), Consejería de Cultura y Turismo Ediciones Trabe, Oviedo: p. 209-221. (in Spanish) ("Excavations in the cave of La Güelga (Cangas de Onis)")

Moncel, M.H., Moigne, A.-M. , Sam, Y. \& Combier, J. 2011, The Emergence of Neanderthal Technical Behavior: New Evidence from Orgnac 3 (Level 1, MIS 8), Southeastern France, Current Anthropology, 52-1: 37-75. doi:10.1086/658179

Monchot, H., Mashkour, M. \& Vigne, J.-D. 2005, Kernel smoothing and mixture analyses for the determination of the sex ratios at death, at the beginning of the domestication of ungulates, In: The First Steps of Animal Domestication. News archaeozoological approaches, Proceedings of the 9th ICAZ Conference, Durham 2002, (Vigne, J.-D., Peters, J., Helmer, D., Eds.), Oxbow Book, Oxford: p. 55-60.

Montes, R. \& Lasheras, J.A. (Eds.) 2005, Neandertales Cantábricos: Estado de la Cuestión, Monografías del Museo Nacional y Centro de Investigación de Altamira Vol. 20, Ministerio de Cultura, Madrid, 617 p. (in Spanish) ("Cantabrian Neandertals. State of Arts")

Normand, C., O'Farrell, M. \& Ríos-Garaizar, J. 2008, Quelles(s) utilisations(s) pour les productions lamellaires de l'Aurignacien archaïque? Quelques données et réflexions à partir des exemplaires de la grotte d'Isturitz (Pyrénées Atlantiques; France), Paléthnologie, 1: 7-46. (in French) ("Which use(s) for the Proto-Aurignacian microbladelet production? Some information and though on the samples from the cave of Isturitz (Pyrénées Atlantiques, France)")

Ortega, I., Ríos-Garaizar, J., Ibáñez Estévez, J.J., González, J.E. 2006, L'occupation de l'Aurignacien Ancien de Barbas III (Creysse, Dorgogne): résultats préliminaires sur la fonction du site, Paléo, 18: 115-142. (in French) ("The Early Aurignacian occupation at Barbas III (Creysse, Dordogne)")

Pelegrin, J., Karlin, C., Bodu, P. 1988, “Chaines opératoires”: un outil pour le préhistorien "au plus grand", In: Technologie préhistorique, (Tixier, J., Ed.), Notes et Monographies Techniques du CRA Vol. 25, Centre national de la recherche scientifique, Paris: $p$. 55-62. (in French) ("Chaines Operatoires: a tool for the prehistorical archaeologist the largest")

Peyrony, D. 1936, Le Périgordien et l'Aurignacien, Bulletin de la Société préhistorique de France, 33(11): 616-619. (in French) ("Perigordian and Aurignacian") doi:10.3406/bspf.1936.5461

Peyrony, D. 1948, Le Périgordien, l'Aurignacien et le Solutréen en Eurasie d'après les derniers fouilles, Bulletin de la Société préhistorique de France, 45(8-10): 305-328. (in French) ("Perigordian, Aurignacian and Solutrean in Eurasia, regarding to the last digs") doi:10.3406/bspf.1948.2393

Pinto-Llona, A.C., Clark, G., Karkanas, P., Blackwell, B., Skinner, A.R., Andrews, P., Miller, A., Macías-Rosado, R., Reed, K. \& Vakiparta, J. 2012, The Sopeña Rockshelter, a new site in Asturias (Spain) bearing evidence on the Middle and Early Upper Palaeolithic in Northern Iberia, Munibe Antropologia-Arkeologia, 63: 45-79.

Plisson, H. \& Schmider, B. 1990, Étude préliminaire d'une série de pointes de Châtelperron de la Grotte du Renne à Arcy-sur-Cure: approche morphométrique, technologique et tracéologique. In: Paléolithique moyen récent et Paléolithique supérieur ancien en Europe, (Farizy, C, Ed.), Association pour la Recherche Archéologique en Ile-de- 
France, Nemours: p. 313-318. (in French) ("Preliminar study of a series of Chatelperron points from the Grotte du Renne, in Arcy-sur-Cure : morphomethrical, technological and traceological approach")

Porraz, G., Simon, P. \& Pasquini, A. 2010, Identité technique et comportements économiques des groupes proto-aurignaciens à la grotte de l'Observatoire (Principauté de Monaco), Gallia Préhistoire, 52: 33-59. (in French) ("Technical identity and economical behaviour among proto-aurignacian groups in the Observatoire cave (Monaco)")

Ríos-Garaizar, J. 2008, Nivel IX (Chatelperroniense) de Labeko Koba (Arrasate-Gipuzkoa): gestión de la industria lítica y función del sitio, Munibe (Antropologia-Arkeologia), 59: 25-46. (in Spanish) ("Level IX (Chatelperronian) of Labeko Koba (Arrasate-Gipuzkoa): lithic industry management and site functionality")

Ríos-Garaizar, J. 2010, Organización económica de las sociedades Neandertales: el caso del nivel VII de Amalda (Zestoa, Gipuzkoa), Zephyrus, 65: 15-37. (in Spanish)

("Economical organization of Neandertal societies: the case of level VII at Amalda (Zestoa, Gipuzkoa)") URL: http://campus.usal.es/ revistas_trabajo/index.php/05147336/article/view/7170

Rios-Garaizar, J., de la Peña, P., San Emeterio, A., 2011. Estudio de las industrias líticas y óseas de la cueva de Aitzbitarte III (Zona de la entrada). In: Ocupaciones Humanas en la cueva de Aitzbitarte III (Rentería, País Vasco) Sector Entrada: 33.000-18.000 BP, (Altuna, J., Mariezkurrena, K., Rios-Garaizar, J., Eds.), Eusko Jaurlaritzaren Argitalpen Zerbitzu Nagusia, Vitoria-Gasteiz: p. 81-351. (in Spanish) ("Study of osseous and lithic industries in the cave of Aitzbitarte III (entrance area)")

Sáenz de Buruaga, J.A. 1991, El Paleolítico superior de la cueva de Gatzarria (Zuberoa,País Vasco), Veleia / Anejo. Series Maior Vol. 6, Universidad del País Vasco, Vitoria (Spain), 426 p. (in Spanish) ("The Upper Palaeolithic in the cave of Gatzarria (Zuberoa, Basque country)").

Sonneville-Bordes, D. 1975, Les listes-types. Observations de méthode, Quaternaria, 18: 9-43. (in French) ("Types-lists. Methodological observations")

Sonneville-Bordes, D. 1985, Variabilités typologiques dans les outillages lithiques.

Remarques sur leurs significations au Paléolithique supérieur, In: La signification culturelle des industries lithiques, (Otte, M., Ed.), B.A.R. International Series Vol. 239, Studia Praehistorica Belgica Vol. 4, British Archaeological Reports, Oxford: p. 391419. (in French) ("Typological variability in lithic tools. Notes on their meanings in the Upper Palaeolithic")

Sonneville-Bordes, D. \& Perrot, J. 1954, Lexique typologique du Paléolithique supérieur.

Outillage lithique: I. Grattoirs. II. Outils solutréens, Bulletin de la Société Préhistorique Française, 51(7): 327-335. (in French) ("Typological Glossary of the Upper

Palaeolithic. Lithic tools: I. End-scrapers. II. Solutrean tools")

doi:10.3406/bspf.1954.3106

Sonneville-Bordes, D. \& Perrot, J. 1955, Lexique typologique du Paléolithique supérieur. Outillage lithique : III. Outils composités-Perçoirs, Bulletin de la Société Préhistorique Française, 52(1-2): 76-79. (in French) ("Typological Glossary of the Upper Palaeolithic. Lithic tools : III. Composed tools-Drills”) doi:10.3406/bspf.1955.3156

Sonneville-Bordes, D. \& Perrot, J. 1956a, Lexique typologique du Paléolithique supérieur. Outillage lithique: IV. Burins, Bulletin de la Société Préhistorique Française, 53(7): 
408-412. (in French) ("Typological Glossary of the Upper Palaeolithic. Lithic tools: IV. Burins”) doi:10.3406/bspf.1956.3357

Sonneville-Bordes, D. \& Perrot, J. 1956b, Lexique typologique du Paléolithique supérieur. Outillage lithique (suite et fin), Bulletin de la Société Préhistorique Française, 53(9): 517-557. (in French) ("Typological Glossary of the Upper Palaeolithic. Lithic tools (following and last)") doi:10.3406/bspf.1956.3374

Tarriño, A. 2006, El sílex en la cuenca Vasco-Cantábrica y Pirineo Navarro: caracterización y su aprovechamiento en la Prehistoria. Monografías del Centro de Investigación y Museo de Altamira Vol. 21, Ministerio de Cultura, Madrid, 263 p. (in Spanish) ("Flint in the Basque-Cantabrian Bassin and the Pyrenees of Navarre: characterization and use during Prehistory")

Texier, P.-J., Brugal, J.-P., Lemorini, C. \& Wilson, L. 1998, Fonction d'un site du Paléolithique moyen en marge d'un territoire: l'abri de La Combette (Bonnieux, Vaucluse). In: Économie préhistorique: les comportements de subsistance au Paléolithique. XVIII Rencontres Internationales d'Archéologie et d'Histoire d'Antibes, (Brugal, J.-P., Meignen, L. \& Patou-Mathis, M., Eds.), Association pour la promotion et la diffusion des connaissances archéologiques (APDCA), Sophia-Antipolis: p. 323-348. (in French) ("Functionality of a Middle Palaeolithic site, in the edge of a territory: the La Combette rockshelter (Bonnieux, Vaucluse)")

Tixier, J. 1996, Technologie et Typologie: dérives et sclerose. Quaternaria Nova, 6: 15-21. (in French) ("Technology and Typology: abuses and sclerosis")

Tostevin, G. 2000, Behavioral Change and Regional Variation across the Middle to Upper Paleolithic Transition in Central Europe, Eastern Europe, and the Levant. $\mathrm{Ph} . \mathrm{D}$ Dissertation, Department of Anthropology, Harvard University. Cambridge (Massachusetts), $492 \mathrm{p}$.

Villa, P., Boscato, P., Ranaldo, F. \& Ronchitelli, A. 2009, Stone tools for the hunt: points with impact scars from a Middle Paleolithic site in southern Italy. Journal of Archaeological Science, 36(3): 850-859. doi:10.1016/j.jas.2008.11.012

Zilhao, J., d'Érrico, F., Bordes, J-G., Lenoble, A., Texier, J-P. \& Rigaud, J-Ph. 2008, Grotte des Fées (Châtelperron): History of Research, Stratigraphy, Dating, and Archaeology of the Châtelperronian Type-Site, PaleoAnthropology, 2008: 1-42. URL: http://paleoanthro.org/media/journal/content/PA20080001.pdf 